直腸癌に抢ける神経温存手術の適応と限界

\begin{tabular}{|c|c|c|c|c|c|}
\hline \multicolumn{6}{|c|}{ 金沢大学第 1 外科 } \\
\hline 哲司 & 橋爪 & 泰夫 & 石田 & 一樹 & 平野 \\
\hline 久幸 & 山脇 & 優 & 川浦 & 幸光 & 岩 \\
\hline
\end{tabular}

\title{
THE INDICATION AND LIMIT OF RECTAL CANCER'S OPERATION FOR CONSERVATION OF THE AUTMATIC NERVOUS SYSTEM
}

\author{
Tetsuji YAMADA, Yasuo HASHIJUME, Kazuki ISHIDA, \\ Makoto HIRANO, Hisayuki NAKAZIMA, Suguru YAMAWAKI, \\ Yukimitsu KAWAURA and Takashi IWA \\ Department of surgery (1), Kanazawa University School of Medicine
}

直腸癌の自律神経温在手術の適応々限界を知るために, 自律神経温存低位前方切除術が施行された 18 症例を対象とし, 術後の自律神経諸機能と予後の面から検討を加えた. 術後の排尿障害の発生率は $6 \%$ （1/18）であり，自律神経非温存手術が $64 \%$ （38/64） と高率であるのに反しきわめて低值であっ た。また術後の性機能も術前と変わりなかった。術後 5 年生存率は $69 \%(11 / 16)$ と決して満足のいく ものではなかったが，（1）術前検查にて腫場径が $3 \mathrm{~cm}$ 未満の Rs, Ra 腫瘍，(2) 術中検査にて No, So 症例に限って本術式を施行すれば予後の面からも満足のいく結果を得られるものと考兄られた。

柬引用哣 : 直晹癌, 自律神経温存手術, 排尿障害, 性機能障害

\section{I.はじめに}

癌の外科治療は根治性を第 1 亿重視する術式が選択 され, 癌巣を含め所属りンパ節, 周囲組織を en bloc $に$ 摘出する手術が基本的術式となっている. 直腸癌の外 科治療潦招いて子抬大郭清が基本的術式となり, 治療 成績の向上が認められるよらになってきた。しかし広 範囲なりンバ郭清に伴なら下腹神経, 骨盤神経, 陰部 神経などの損傷のため, 術後の排便, 擦尿, 性機能障 害を大多数の患者隹認めている. 患者を生涯苦しめる これらの機能低下は, 進行癌が大多数を占め絶対的な 補助療法のない現在までは問題とされず, 根治性が優 先されてきたのは当然のことである。

しかしながら直腸内視鏡検査の進歩に伴ない，早期 癌が增加し1)，機能低下をきたす拡大郭清233)を盲目的 にすべての症例仵行するのは過剩手術であり根治性 を損わない範囲で機能温存をはかる術式を選択すべき 症例もしだいに増加してきている。そのためわれわれ

$<1985$ 年 5 月 15 日受理 $>$ 別刷請求先 : 山田 哲司 干920 金沢市宝町 $13-1$ 金沢大学医学部第 1 外科
は比較的早期の直腸癌患者を対象として, 自律神経温 存低位前方切除手術を行ってきたので，その結果を報 告すると同時に本術式の適応と限界に検討を加えたの で報告する。

\section{II. 対象および方法}

1971年から1981年までに当科で入院治療をうけた直 腸癌症例は114例であった。このうち114例に何らかの 外科治療がなされ，99例において切除が可能であった (切除率 $86 \%$ ) (表 1). この5ち自律神経温存低位前方 切除手術がなされたのは大腸癌取り扱い規約による $\mathrm{Rs}$ 癌 11 例, $\mathrm{Ra}$ 癌 6 例, $\mathrm{Rb}$ 癌 1 例の計18例を今回の検 討の対象とした。男性10例，女性 8 例であり平均年齢

表 1 直腸癌手術症例 (1971 1981)

\begin{tabular}{|c|c|c|c|c|}
\hline & 治源手術 & 非治港手術 & 姑息手桷 & it \\
\hline Rs & 13 & 4 & 2 & 19 \\
\hline $\mathrm{Ra}$ & 16 & 3 & 6 & 25 \\
\hline $\mathrm{Rb}$ & 46 & 3 & 6 & 45 \\
\hline$P$ & 9 & 5 & 1 & 15 \\
\hline $8+$ & 84 & 15 & 15 & 114 \\
\hline
\end{tabular}


表 2 自律神経温存低位前方切除手術症例

\begin{tabular}{c|c|c|c}
\hline & 男性 & 女性 & \multicolumn{1}{c}{$\mathrm{st}$} \\
\hline $\mathrm{Rs}$ & 5 & 6 & 11 \\
$\mathrm{Ra}$ & 4 & 2 & 6 \\
$\mathrm{Rb}$ & 0 & 1 & 1 \\
\hline $\mathrm{st}$ & 9 & 9 & 18 \\
\hline
\end{tabular}

は60.3歳であった（表 2 ）。

本術式選択の基準としては, 術前の内視鏡検查にて, 肉眼型は限局潰瘍型もしくは表在型, 腫疸型が $3 \mathrm{~cm}$ 以 内のものであり, 術中 $\mathrm{No}$, So, Po, Ho と判断したも のとした.

本術式の要点は, 下腸間膜動脈はできるだけ根部で 結紮するが, 大動脈前面の下腹神経叢はさわらない。 左右の総腸骨動静脈の血管床の剶離は行わず, 血管床 にまとわりついて走行する下腹神経の損傷をさける. 直腸後面の剥離は大動脈周井の下腹神経刹離層より深 く入らないようにし，骨盤神経の損傷をさける。中直 腸動脈は直腸癌に入る部分で結紮し，根部での結禁は 行わないなどが上げられる。本術式は大腸癌取り扱い 規約によれば, Rs 腫場では $\mathrm{R} 2, \mathrm{Ra}$ 腫場では R1の郭清 が行われることとなると考光ている.

III. 結 果

本術式を施行した18例の切除標本の病理組織検査で は高分化腺癌11例, 中分化腺癌 7 例であった（表 3 ).

手術内容は絶対治癒手術 15 例, 相対治癒手術 2 例,

表 3 癌占居部位と組織との関係

\begin{tabular}{|c|c|c|c|}
\hline & 高分化腺癌 & 中分化腺癌 & st \\
\hline Rs & $6^{*}(1)$ & $5^{*}(1)$ & $11^{* *}(2)$ \\
\hline $\mathrm{Ra}$ & $4(2)$ & $2(1)$ & $6(3)$ \\
\hline $\mathrm{Rb}$ & $1(0)$ & & $1(0)$ \\
\hline 尌 & $11^{*}(3)$ & $7^{*}(2)$ & $18^{*}(5)$ \\
\hline
\end{tabular}

表 4 自律神経温存低位前方手術症例

\begin{tabular}{|c|c|c|c|c|}
\hline & \multicolumn{2}{|c|}{ 活切除 } & \multirow{2}{*}{ 翡治賈切除 } & \multirow{2}{*}{81} \\
\hline & 乘刘治愿切除 & 相対治活切除 & & \\
\hline Rs & $10^{*}(1)$ & $1(1)$ & & $11^{*}(2)$ \\
\hline Ra & $4(1)$ & $1(1)$ & $1(1)$ & $6(3)$ \\
\hline $8 b$ & $1(0)$ & & & $1(0)$ \\
\hline s̀t & $15^{*}(2)$ & $2(2)$ & 1(1) & $18(5)$ \\
\hline
\end{tabular}

相対非治滺手術 1 例であった。 11 例が 5 年生存した。 他病死亡症例を除いて再発は 5 例にみられ, 絶対治瘾 切除手術での 5 年生存率は $85 \%$ (11/13) であった。 た全症例の 5 年生存率は $69 \%(11 / 16)$ であった(表 4 ).

術後の排尿機能をみるために，当科で行われた腹会 陰式, 仙骨腹式, 前方切除術症例の術後尿管カテーテ ル留置日数をしらべてみたところ, 自律神経温存手術 でのカテーテル留置期間はきわめて短期間であった (表 5 )。 また排尿障害発生頻度をみても神経温存手術 での排尿障害はまれであり，排尿機能はきわめて良好 であった（表 6 ).

また性機能をみてみると，10例の男性のうち8例が 術前性生活があったが, 術後 6 力月後には全例術前と 変らない性生活が可能であった。

排便回数は本術式施行例では術後 3 週目には全例 1 日 1 2 回の排便回数であり, 自律神経非温存低位前 方切除術式が 1 日 $6 \sim 7$ 回の排便回数であったのに比 べきわめて良好であった。

本術式に詳細な検討を加兄るため, 癌占居部位とリ ンパ節転移で症例を分類すると, $\mathrm{n}_{0}$ が 13 例, $\mathrm{n}_{1}$ が 3 例, $\mathrm{n}_{2}$ が 2 例であり, $\mathrm{n}_{0}$ で 2 例, $\mathrm{n}_{1}$ で 1 例, $\mathrm{n}_{2}$ で 2 例が再発 死しており $\mathrm{n}_{0}$ 症例の 5 生率は $82 \%$ (9/11)であった(表 7 ).

表 5 尿管カテーテル抜去までの平均日数

\begin{tabular}{|c|c|c|c|}
\hline & & 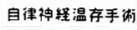 & 自律神释非温存手溯 \\
\hline & 閥会除式 & $6 \mathrm{~B}$ & $14 \mathrm{~B}$ \\
\hline & 仙骨腹式 & & $17 \mathrm{~B}$ \\
\hline 肛阳温存手術 & 前方切除 & 4 日 & 7 \\
\hline
\end{tabular}

表 6 直腸癌手術之術後排尿障害

\begin{tabular}{|c|c|c|c|}
\hline & & 自律神释温存手袖 & 目律神轻非温存手術 \\
\hline 面路切必淋 & 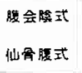 & - & $\begin{array}{l}20 / 34(58) \\
18 / 25(72)\end{array}$ \\
\hline 肛門温車乎淋 & 前万切除 & $1 / 18(6)$ & \\
\hline \multicolumn{2}{|c|}{$g+$} & $3 / 32(9)$ & $38 / 59(64)$ \\
\hline
\end{tabular}

表 7 癌占居部位とリンパ節転移との関係

\begin{tabular}{|c|c|c|c|c|}
\hline & $n_{0}$ & $n_{1}$ & $n_{2}$ & s十 \\
\hline Rs & $\mathbf{B}^{*}(1)$ & $2(0)$ & $1(1)$ & $11^{*}(2)$ \\
\hline Ra & $4(1)$ & $1(1)$ & $1(1)$ & $6(3)$ \\
\hline $\mathrm{Rb}$ & $1(0)$ & & & $1(0)$ \\
\hline 計 & $13^{* *}(2)$ & $3(1)$ & $2(2)$ & $18(5$ \\
\hline
\end{tabular}


表 8 癌占居部位と組織学的壁深達度との関係

\begin{tabular}{|c|c|c|c|c|c|c|}
\hline & $m$ & sm & $\mathrm{Dm}$ & $s s$ (a) & $s(a)$ & H \\
\hline As & $1(0)$ & & $3^{4}(0)$ & $6(2)$ & $1<0$ & $\pi 1(2)$ \\
\hline $\mathrm{Ra}$ & & $1(0)$ & $1(0)$ & $1(0)$ & $3(3)$ & $6(3)$ \\
\hline Ro & $1(0)$ & & & & & $1(0)$ \\
\hline 87 & $2(0)$ & $1(0)$ & $4^{*}(0)$ & $f^{7}(2)$ & $4(3)$ & $181(5)$ \\
\hline
\end{tabular}

表 9 リンパ節転移と組織学的壁滐達度との関係

\begin{tabular}{|c|c|c|c|c|c|c|}
\hline & $\mathrm{m}$ & $\mathrm{sm}$ & $\mathrm{pm}$ & $=s(a)$ & $\Rightarrow$ (a) & - $8+$ \\
\hline no & $2(0)$ & $1(0)$ & $2(0)$ & $6(1)$ & 2(1) & $13(2)$ \\
\hline$n_{1}$ & & & $2(0)$ & & $1(1)$ & $3(1)$ \\
\hline $\mathrm{n}_{2}$ & & & & $1(1)$ & 1(1) & 2(2) \\
\hline 8t & $2(0)$ & $1(0)$ & $4^{*}(0)$ & $7^{*}(2)$ & $4(3)$ & $18(5)$ \\
\hline
\end{tabular}

表10 腫鈞径と深達度との関俰

\begin{tabular}{|c|c|c|c|c|c|c|}
\hline 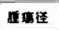 & $m$ & $\mathrm{sm}$ & om & ss(aI) & $s\left(a_{2}\right)$ & st \\
\hline$\sim 3 \mathrm{~cm}$ & & $1(0)$ & $2(0)$ & $t(0)$ & & $4(1)$ \\
\hline$\sim 4 \mathrm{~cm}$ & $2(0)$ & & $1(0)$ & $3(1)$ & (1) & $7(2)$ \\
\hline$\sim 5 \mathrm{~cm}$ & & & $I^{*}(0)$ & $i(0)$ & $1(0)$ & $3^{* *}(0)$ \\
\hline$\sim 6 \mathrm{~cm}$ & & & & 2(1) & $2(2)$ & $4(3)$ \\
\hline \&4 & $2(0)$ & $1(0)$ & $4(0)$ & $7(2)$ & $4(3)$ & $18(5)$ \\
\hline
\end{tabular}

癌占居部位と壁深達度との関係では $\mathrm{pm}$ 以下の症例 には再発死はないものの, ss 以上の症例は $50 \%$ が再発 死していた（表 8 ）。

リンパ節転移と壁深達度との関俰をみると $\mathrm{pm}$ 以下 の症例はたと光ンン゚節転移はあっても再発を認めな いが, ss 以上の症例ではリンパ節転移がなくても再発 死を29\%（2/7）に認めた（表 9).

切除標本の腫瘍の最大径と壁深達度との関係をみる と, 畽瘍径の大きいものほど壁深達度が大きいのは当 然のことながら，直腸鏡や内視鏡検查にて直径 $3 \mathrm{~cm}$ 以 下のものを対象としたにもかかわらず，5６cm まで のものが 4 例も含まれて招り術前検查の再考が必要と 思われた（表10）。

再発 5 症例の再発様式は，局所再発 3 例，肝及び肺 転移 2 例, 癌性腹膜炎 2 例（重複症例がある）であり， 局所再発の 3 例はいずれも Rs, $\mathrm{Ra}$ の $\mathrm{S}\left(\mathrm{a}_{2}\right)$ 症例で あった。

\section{IV. 考 案}

当科で施行された自律神経温存低位前方切除手術症 例に検討を加觉たところ，術後の自律神経諸機能の面 からはきわめて満足のいくものであったが，予後の面 では 5 例にリンパ節及び遠隔転移による再発死亡を認 め, 必ずしも満足のいくものではなかった。
本術式の目的は根治性を損うことなく, 自律神経諸 機能を温存することにあり，そのためさらに厳密な適 応と，限界を十分に知った上での症例の選択の必要が あると考光られた。

われわれの症例は組織学検査にて高分化腺癌11例, 中分化腺癌 7 例であったが，既に報告したよ5に大腸 癌に扔いては中分化腺癌や，粘液癌では局所再発，血 行性転移をさたしやすいことより，本術式は高分化腺 癌に限った方が良いと思われた ${ }^{4) 5}$.

われわれの症例はいずれす術中 No と判断しながら $\mathrm{n}_{0}$ はわずか $72 \%$ (13/18) であり, $\mathrm{n}_{1} 17 \%$ (3/18), $\mathrm{n}_{2}$ $11 \%(2 / 18)$ と高率にリンパ節転移を認め， $\mathrm{n}_{2}$ 症例はい ずれも再発により死亡していた。リンパ節郭清不足が， 再発死亡の原因の 1 つであると思われた，土屋らは神 経温存術式に打いても十分に側方郭清は可能であると 述べている゙年が，われわれは自律神経諸機能を温存し ようとすれば十分なる側方郭清は不可能であると考え ている，そのため本術式を選択した場合の No 決定に は慎重な態度が必要と思われた。大見は Rs, Ra などの 上部進行直腸癌の転移陽性率を $40.6 \%^{7)}$, 高橋は Ra で $41.5 \%$ であると ${ }^{8)} し ， と り わ け 251$ 番のリンパ節転移率 が高いと報告している.さらに大見は直径 $2 \mathrm{~mm}$ 以下の リンパ節でも組織学的検討を行えば転移を認める場合 があると報告9して括り，肉眼所見のみによるリンパ 節転移の有無の判定には困難があると思われる，その ため今後はサンプリングした251番のリンパ節の迅速 標本にてNoを確認の上，本術式を採用した方が良い と思われた。

Rs 癌においては小山は23例中いずれにしても側方 転移を認めず10)，大見らはRs の 1 例に側方転移を報

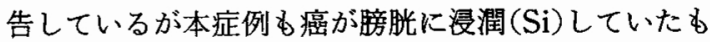
ので，この部位からリンパ節に転移したものではない かと推論している7)、いずれにしてす Rs 癌においては 上方転移が優勢であるが，側方転移はをれであると思 われる，そのため側方郭清が十分でない本術式の欠点 も問題とならず, 術中迅速標本にて251番, リンパ節転 移(一) である No Rs 症例は本術式の良い適応と考兄 られる。

$\mathrm{Ra}$ 症例に扔いてわれわれの成績では 5 年生存率が わずか $50 \%$ であり，十分な側方郭清不可能な本術式の 選択にはRs 腫場よりさらに慎重な態度が必要である 之思われた，Ra腫瘍に招ける側方転移は，高橋は $8 \%^{8)}$ ，小山は $10 \%{ }^{10)}$ ，大見は $11 \%{ }^{7)}$ と報告している. しかし大見は上方転移がなく，側方転移のみが認めら 
れる症例はまれであり，上方転移（とりわけ251番）と 側方転移の両方を持っことが多いと報告し7，更に安 富は腫場径が $4 \mathrm{~cm}$ 以下のものは側方転移が少ないと 述べている11)，以上を考光合わせれば Ra 腫瘍に本術 式を採用する場合には，術中迅速標本による251番リン パ節転移 (一) の, 腫瘍径が $3 \mathrm{~cm}$ 未満のbのに限った ほうが良いと思われた。

$\mathrm{Rb}$ 腫瘍においては側方転移のみならず，下方転移 もあることより $\mathrm{Rb}$ 腫瘍は本術式の適用より除外した ほらが良いと思われた。

術中 So 症例のみを選択したはずのわれわれの症例 む, 組織学的検查にて半数以上が ss 以上であり, 術中 判断の甘さが予後不良の一因ともなっている。しかし 山村らはSo 46症例のらち38例は Pm 以下であり So 之判定した場合には肉眼的浆膜漫潤と組織学的深達度

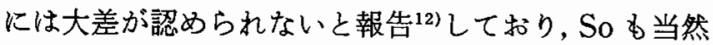
本術式選択の基準に加壳たほうが良いと思われた。

術前検查にて腫瘍径が $3 \mathrm{~cm}$ 末満としたものに対し 本術式を選択したにもかかわらず，切除標本でも腫場 径が $3 \mathrm{~cm}$ 末満であったのはわずか $22 \%(4 / 18)$ であっ た. 直腸癌の場合病態によっては術前検査のみにて腫 瘍径の正確な同定は不可能であり，切除標本を手術場 にて切開, 腫瘍径の計測が望ましいと思われた。とり わけ Ra 腫㻛に対しては, このことが重要であり, $3 \mathrm{~cm}$ 以上のものに対しては側方郭清を追加するべきと，思 われた。

以上当科で施行された自律神経温存低位前方手術症 例に検討を加えた。

\section{V. 結 語}

当科で施行された18例の自律神経温存低位前方手術 症例に検討を加え次の結論をえた。

（1）本術式は自律神経機能温存術式としてはすぐれ ていた。

（2）腫瘍径 $3 \mathrm{~cm}$ 未満の No, So の Rs, Ra 腫瘍が本
術式の適応となる。

（3）リンパ節転移の有無の決定には251番リンパ節 の迅速標本にて決定する必要がある。

\section{文献}

1）陣内伝之助, 福原 毅: 早期大腸癌の特徵と治療 方針。消外 $3: 1803-1808,1980$

2）安富正幸, 麻生礼三：直腸癌手術後の性機能障害 および排尿障害。手術 $28: 571-579,1974$

3）江口英雄, 大木栄男, 土屋周二：直腸癌に扰ける拡 大郭清の意義一拡大郭清と機能障害. 臨外 35 ： 1014-1019, 1980

4）山田栄吉, 山田満昭, 加藤壬干ほか：病理組織学的 立場からみた直腸癌再発の特殊性について。最新 医 33：211-2118, 1978

5）山田栄吉, 加藤壬干, 加藤知行 : 進行直腸癌に対す る姑息的手術之合併㞠法。消外 6:675-680, 1983

6）土屋周二, 池 秀之, 大木繁男注：大腸癌の手 術。自律神経を温なする直腸癌手術。手術 37 ： 1367-1373, 1983

7）大見良裕：直腸癌のリンバ節転移の検討，日外会 誌 $81: 676-687,1980$

8）高橋 孝, 北条慶一, 西 满正ほか：リンパ節転移 々外科治療一discussion一大腸癌診断治療の最新 の進歩. 東京, へるす出版, 1982, p95-108

9）大見良裕, 土屋周二, 大木繁男沙：直腸癌に拈け る側方転移扣よび非転移リンバ節の大きさ，日消 外会誌 $16: 902-910,1983$

10）小山靖夫, 高橋 小山靖夫, 高橋 孝, 北条度一区 か：リンパ節転移と外科治療一discussion一大腸 癌診断治療の最新の進歩. 東京, へるす出版, 1982, p95-108

11）安富正幸, 泉本源太郎, 西山真一洁加：大腸潞手術 におけるリンパ節郭清と補助化学療法。日消外会 誌 $17: 821-825,1984$

12）山村卓也, 矢部清寿, 田中洋一潘 : 大腸癌におけ るリンパ節転移の検討. 日消外会誌 $16: 75-79$, 1983 